\title{
A Culture of Ecumenical Convergence? Reflections on the Czech Experience
}

\author{
JAROSLAV KREJČÍ
}

Ecumenism is usually understood as the aspiration to overcome rifts and schisms within the Christian body social. I shall be considering this aspect of ecumenism; but I shall also be considering the idea of ecumenism in a wider sense. It is my contention that the prospects for cooperation between people of various convictions in matters of ultimate concern are brighter now that Marxism-Leninism, with its militant opposition to religion, has left the scene.

As is well known, the divisions within Christianity have very diverse origins. In the country that is the subject of this study, the Czech part of Czechoslovakia, the main division dates back to the 15 th century. This is 100 years before the CatholicProtestant split occurred in other parts of Europe (Slovakia included). The result, nevertheless, is that Czech society is split on lines similar to those found in other societies that experienced the great transformative movements of Western European culture: the Renaissance, the Reformation, the Enlightenment and the Romantic movement. An additional factor in the case studied here is the role of MarxismLeninism.

Of all these cultural upheavals only the Reformation and the reaction to it, the Counter-Reformation, produced in Christianity a rift that still has to be healed. All the others affected Christianity from the outside. Certainly these other upheavals were all characterised by non-Christian values. The Renaissance and the Romantic movement, the former with its philosophical articulation in humanism and the latter with its most vigorous offshoot, modern nationalism, were able to exist side by side with Christianity. Nevertheless, although they did not question the Christian faith at a basic level, they did challenge its exclusive claim to human souls; humanism and nationalism have therefore occasionally appeared as competitors with Christianity. The Enlightenment offers a more complex case: its sceptical approach to fideism mitigated denominational differences, but at the same time it brought into question the very rationale of religious belief. Finally, Marxism was a direct foe. In its Leninist version it involved a concerted attack on religion, for which it claimed to be the 'enlightened' substitute. Having abandoned the open-minded pragmatism of the Enlightenment, however, Marxism-Leninism presented itself ultimately as just another kind of fideism, which, unfortunately for its own credibility, was built on premises amenable to empirical verification.

Each of the aforementioned cultural upheavals left its mark on the relations between the various Christian denominations. In order to understand the present prospects for ecumenism we have to review the main obstacles to it. As far as Christian ecumenism is concerned, these obstacles stem mainly from the duality of the Catholic-Protestant Christian tradition. 
The Czech Reformation, as already noted, preceded the European Reformation by 100 years. Its main hero and martyr was Jan Hus, who was condemned for heresy at the Council of Constance and burnt at the stake (6 July 1415). This event is not merely a fact of history, but a living memory in the nation. Between Catholics and Protestants it is the main impediment to a genuine understanding. The common programme of Hus's followers, the Utraquists or the Calixtins, was formulated in the Four Articles of Prague, which in their final version of October 1420 read:

1 That the Word of God shall be freely and without hindrance proclaimed and preached by Christian priests in the kingdom of Bohemia.

2 That the Holy Sacrament of the body and blood of Christ under the two kinds of bread and wine shall be freely administered to all true Christians who are not excluded from communion by mortal sin.

3 That since many priests and monks hold many earthly possessions against Christ's command and to the disadvantage of their spiritual of fice and also of the temporal lords, such priests shall be deprived of this illegal power and shall live exemplary lives according to the Holy Scripture, in following the way of Christ and the Apostles.

4 That all mortal sins, and especially those that are public, as also other disorders contrary to the divine law, shall be prohibited and punished by those whose office it is so that the evil and false repute of this country may be removed and the wellbeing of the kingdom and of the Bohemian nation may be promoted. ${ }^{1}$

Paradoxically, of all the Hussite requirements it was the Eucharist in both kinds for the laity that constituted the most serious stumbling-block in negotiations for a compromise with the Roman Church. This point could not be diluted or reduced to insignificance like the other three requirements.

The result of bloody wars was a compromise at the Council of Basel. Under the influence of the Renaissance, this period of strife was followed by a period of recuperation; but the European Reformation, in which Luther and Calvin were the main protagonists, found a lively resonance in Bohemia and Moravia, and produced a new rift in the nation. This time the German speakers in the country were also involved. The influence of the Renaissance and humanism was gradually superseded by radical fervour on both sides of the divide. The ultimate outcome was armed confrontation again - the first round of the Thirty Years' War, in which the Protestants of Bohemia and Moravia, both Czech and German, were unable to sustain their cause.

For the Czechs, enforced reconversion to Catholicism produced far graver consequences than did the Counter-Reformation elsewhere. Indeed, the legacy of the Counter-Reformation in Bohemia and Moravia is a recurrent trauma in the national consciousness. Before 1620 , when the Protestant aristocracy of Bohemia rose against their Habsburg king and suffered a decisive defeat, almost 90 per cent of the population of Bohemia was Protestant. Most were Lutherans, while a minority belonged to a more compact and consolidated Unity of Brethren, which kept on good terms with Calvinists abroad. In Moravia, which had a population about half that of Bohemia, Catholics and Protestants were approximately equal in number. After 1620, all Protestant denominations were banned-even the smallest and most traditional, the Utraquists, who differed from the Catholics only in the form of the eucharist for the laity. The latter were included in the ban for pragmatic reasons: if they had been left out all the other Protestants would have joined them and religious pluralism would have been preserved, albeit in an attenuated form. The triumph was 
intended to be complete, and so it was. When, after 160 years, an enlightened monarch (Joseph II) readmitted a carefully defined measure of religious pluralism to his domains, barely 2 per cent of the population of Bohemia and Moravia registered as members of the two permitted Protestant denominations, the Augsburg (Lutheran) Confession and the Helvetic (Calvinist) Confession. Large-scale enforced reCatholicisation took place in other countries as well, such as France, Austria and parts of Germany. On a minor scale, and with less use of force, the CounterReformation also succeeded in Poland. But in none of these countries had people been involved in, and identified with, the Reformation to the extent that the Czechs had been, partly because the Reformation had a much longer tradition in the Czech lands.

The ban on Protestantism in Bohemia and Moravia resulted in large-scale emigration and strict censorship. A great part of the Czech literature produced between 1420 and 1620 was destroyed. The Czechs were deprived not only of their majority religion but also of most of their cultural and political elite. Baroque culture, dominated as it was by art and faith, was a potential stimulus to the population to embrace the Catholic creed and to adopt the veneration of saints, especially the Virgin Mary. But in fact it had no power to counteract the debilitating effects of depopulation, the consequence of war and emigration, or to uphold literacy levels. The number of potential producers and consumers of Czech literature was reduced to a minimum. For one or two generations the Czech language was cultivated by exiles abroad, but this could not offset the 200-year gap in the continuity of its use at home. What was good for the Catholic Church thus turned out to be not so good for the Czech nation. The Counter-Reformation elsewhere produced different results. Most French, Austrians and above all Poles identified themselves with Catholic culture; there was no gap in the literary and cultural development of the French, German and Polish languages.

When the Czechs reemerged as an independent nation after the First World War they remained, on the whole, formal members of the Catholic Church but, as in Third Republic France, a large section of the population exhibited undisguised anti-church attitudes. There was a widespread feeling that political emancipation had to be followed by cultural emancipation as well. This implied not only wider contact with Western European cultures - especially French - at the expense of German culture, but also a weakening of the link with, or even a withdrawal from, the Roman Catholic Church. As the record of Habsburg rule could not be dissociated from the forceful reimposition of the Catholic religion on the whole population of Bohemia and Moravia, nor from the corresponding demise of the Czech language, the Catholic Church could not be spared the discomfort of the downfall of that dynasty.

Some Catholic clergy had organised themselves as a modern Catholic movement even before the First World War. Now, motivated partly by strengthened national feelings and partly by doubts concerning orthodox Catholic dogma, they attempted to introduce reforms, proposing the abolition of celibacy and the use of the vernacular in services. As their proposals were acceptable neither to Rome nor to the local episcopate, they decided to break away. They eventually founded, after a certain flirtation by some with Serbian Orthodox Christianity, the Czechoslovak Church. It was natural that this church would try to establish continuity with the Hussite tradition, especially in liturgy, ritual and episcopal organisation; but at the same time the new church preferred to shape a theology compatible with developments in Europe over the previous two centuries. The theology of the Czechoslovak Church very closely approached that of the Unitarians.

For many Czechs, this development appeared to be a compromise solution. They 
preferred simply to leave the Catholic Church and not to join any other. (There were also a few who preferred a more thorough religious conversion than that offered by the Czechoslovak Church and joined the Evangelical, i.e. Protestant, Church of Czech Brethren, which provided genuine historic continuity with the tradition of the Czech Reformation.) The bulk of those defecting from the Catholic Church, then, either joined the new Czechoslovak Church or declared themselves 'without confession'. A special voluntary organisation was set up under the name of 'Free Thought' to advise those who wanted to leave the Catholic Church on the proper procedure for doing so. (As the Czechoslovak state subsidised officially acknowledged churches, and a part of the subsidy was assessed according to the number of their membership, a proper procedure when leaving a church was considered important.) 'Free Thought' also aspired to give spiritual guidance to people without religious convictions by organising lectures and publishing books and journals.

Thus in the early 1920s, under the slogan 'Away from Rome', the Czech lands experienced a sort of Kulturkampf - a situation most unfavourable for any kind of ecumenical endeavour. The struggle for ecclesiastical buildings and other property that ensued between, on one side, the dissident clergy who joined the Czechoslovak Church and, on the other, the Catholic Church was so bitter that a law passed in 1921 by the Czechoslovak parliament, to protect individuals against intimidation during public meetings, explicitly mentioned religious intimidation, in addition to social (class-based) and ethnic (nationalistic) intimidation, as one of the main threats to peace in the country.

The strife culminated in the demonstrative departure of the papal envoy from Prague on 6 July 1925. The immediate cause of his departure was government participation in memorial celebrations of Jan Hus' execution on 6 July 1415, now proclaimed a state holiday. In response, diplomatic relations with the Vatican were broken off - although three years later a modus vivendi was negotiated with the Vatican.

Despite its ultimate failure, the 'Away from Rome' movement significantly changed the religious structure of the Czech lands. Most changes in allegiance occurred in the early 1920 s but the shift continued throughout the whole period of the First Republic (1918-38) and to a small extent even after the Second World War. In the late 1940s the Czechoslovak Statistical Office was still recording a moderate shift from the Catholic to the Czechoslovak and Protestant Churches. ${ }^{2}$

Meanwhile, a new factor had come into play. A wide spectrum of non-believers and believers, atheists (humanists), deists and theists for whom no institutionalised religion was acceptable, generally known as 'free thinkers', came under the increasing influence of straightforward atheism along Marxist lines. The 41 years of communist domination (1948-89) brought about significant changes, both in the structure of religious affiliation and in the relationship between individual denominations. Churches were cleared of those whose allegiance was only lukewarm and those who remained were strengthened in their resolve.

The prime target of repression was the Roman Catholic Church, to which threequarters of the population were affiliated. Hoping to drive a wedge between the episcopate and the rank-and-file clergy, the communist government was not interested in separation of church and state. By continuing to pay the salaries of the clergy, the state reserved to itself a powerful weapon with which to influence their behaviour. The clergy, however, hesitated to declare full loyalty to the state, because in their minds this would have implied a schismatic separation from the rest of the Catholic Church and from the Pope in Rome. The communists accordingly set up and 
sponsored an association of loyal priests, the 'Peace Committee of Catholic Clergy'. (This disintegrated in 1968 and was reconstituted in the early 1970 s as 'Pacem in Terris', named after the Papal Encyclical of 1963.) At the same time the task of educating children was made the exclusive responsibility of the state; it would carry this out 'in the spirit of the scientific truth of Marxism-Leninism'. As most priests refrained from joining the Peace Committee, punitive measures were taken. During the period 1949-51 religious orders were dissolved, church administration and the pastoral activity of the clergy were put under state control and priests who had not taken the oath of allegiance to the government were dismissed. In the event that they opposed government policy, they were imprisoned. These measures had most effect on the bishops, whose offices were left vacant as a result.

In comparison with the Catholic Church in, for instance, neighbouring Poland the church in Czechoslovakia had little authority over its members and could reach only a small proportion of the population through the pulpit. This was apparently the main reason why the communists could afford more resolute policies in the Czech lands than in Poland. The struggle, however, was harder in Slovakia, where the population was more religious and, in several instances, did not hesitate to defend their priests physically from arrest or deportation.

The pressure on the other churches was less severe. One important factor was that their leadership was not located abroad. Moreover, there was enough good will in the ranks of the Czechoslovak Church to make cooperation with the communists possible. The main Protestant church, the Church of Czech Brethren, was too small and too closely knit to merit disruption; a degree of sophisticated collaboration with the communist authorities by its leading theologian, Josef Hromádka (widely known abroad), also eased the position of this church. Nevertheless, even the non-Catholic churches were subject to watchful state control. Religious education was squeezed out of schools. The exercise of pastoral work was made dependent on the consent of the state supervisory office, as was any activity extending beyond the compass of individual parishes. Too often government consent was withdrawn from individual ministers.

In their wish to present their policy as a culmination of the progressive trend in Czech and Slovak history, the communists tried to interpret the Hussite reformation as a kind of social revolutionary movement that was articulated in religious terms and symbols only because of the spirit of the time. Consequently, the whole Protestant Reformation was viewed more favourably than the Catholic periods in Czech and Slovak history. In following this stratagem, the communists performed a disservice to the Protestant cause. Contrary to their intention, by turning the Catholic Church into a suffering church the communists purged it of opportunistic elements and reestablished its moral standing and prestige. More than anything else they contributed to its full rehabilitation among those Czechs who had until then harboured reservations concerning its past record.

The preference of the communists for the Protestant tradition in general and the radical Hussites in particular prompted some radical Catholics to revive the polemics that had stirred Czech society more than half a century earlier. They hailed the Counter-Reformation of the 17 th and 18 th centuries as a salutary measure, and were critical not only of the Protestant tradition but of the Enlightenment as well, as the crucible of unbelief and the ultimate origin of Marxism. Fortunately, however, the highest representatives of the Catholic Church took, at least with respect to the Protestant tradition, a conciliatory stance and the great majority of the faithful followed their lead, apparently wholeheartedly. The Czech primate, Cardinal Karel 
Beran, was ready to admit wrongdoings in the past but preferred to apportion the blame to the secular rather than the ecclesiastical authorities. At the Second Vatican Council, on 20 September 1965, he said:

So it seems that in my country also the Catholic Church still suffers because of what in the past was done in her name against freedom of conscience: for example, in the 15 th century, the burning of the priest Jan Hus at the stake, or, in the 17 th century, the forcible return of a great part of the Czech nation to the Catholic faith, according to the then valid principle cuis regio eius religio. Secular power, even if it wants to serve the Catholic Church or even if it just pretends to do so, in reality inflicts a permanent, hidden wound on the heart of the nation. ${ }^{3}$

Many Catholics take the view that not only the execution of Hus by the secular authorities but also the sentence itself, which was passed by the Council, was wrong and that Hus should be rehabilitated. But as his sentence was not only a matter of theological judgement but also a matter of canon law, this request remains for the church a questio disputata. Paradoxically, it has been easier for the Catholic hierarchy, including Pope John Paul II, to make conciliatory statements about Martin Luther than about Jan Hus. The Catholic Church's stance on Hus is a hindrance for Czech Christians involved in ecumenical endeavours. One dedicated Czech Catholic described this painful position as follows:

Without coming to terms with Jan Hus, in the sense of a mature interpretation that would make it possible to award him a proper place within its own tradition, Catholicism will always be an alien, 'Protestant' factor in its own nation. ${ }^{4}$

The successor to Cardinal Beran, Cardinal František Tomášek, went a step further. In his ecumenical message for Easter 1988, in which he announced a Ten-Year Programme of Spiritual Renewal, he made the following statement:

When looking to the past we all have reason to call for mercy and forgiveness. The Catholic Church does not disguise its share of guilt for the regrettable chapters of our history (as described, for instance, by Cardinal Beran at the Second Vatican Council, regarding the burning at the stake of Jan Hus and the violence accompanying the recatholicisation of Bohemia after 1620). We hope that our ten-year programme will help us to avoid protracting the discord of our past into the new millennium. ${ }^{5}$

Unlike his predecessor, Cardinal Tomášek thinks that the church itself is to blame. Although caution continues to prevail as far as the sentence on Hus is concerned, the church now allows open criticism of its past policies and expresses genuine regret.

It is good that as a quid pro quo this acknowledgement of guilt on the Catholic side has received a positive reciprocal response from a group of 13 Protestants, all prominent anticommunist activists. In June 1988 this group wrote an open letter to the Central Committee of the Communist Party of Czechoslovakia. In it they stressed their solidarity with Catholic demands for the restitution of their educational and publishing facilities and for the reopening of monasteries; they also acknowledged that the Catholics had been exposed to harsher repression than they themselves had suffered. Last but not least, the Protestant speakers expressed their shame for the fact that they had not stood up earlier for their Catholic fellow-Christians. ${ }^{6}$ A conciliatory mood has begun to prevail on both sides of the traditional divide. Even the 
Czechoslovak Church, which has meanwhile added the attribute 'Hussite' to its name, has been quick to dissociate itself from its generally good relationship with the former communist rulers, and to join in the general quest for harmony.

A start has thus been made on healing a wound that has remained open for more than 300 years. It seems that tolerance has ceased to be a mark of indifference; on the contrary, communist pressure and the suffering of believers have helped to develop a deeper type of religiosity characterised by empathy. On the spiritual plane, MarxismLeninism has suffered a crushing defeat. Moreover, it has lost its credentials as a science. In maintaining their dogma in the face of all empirical evidence, Marxists were proffering a religion devoid of any content. This fact is of particular relevance for the further development of the ecumenical movement, especially if it aspires to reach beyond the confines of the Christian fold. Whatever Marx might have said or believed, it has been demonstrated that Marxism-Leninism has not worked to further the traditions of the Enlightenment but to negate them. If, at the outset, Marxists really believed that they were developing the ideas and values of the Enlightenment, their practical performance in all walks of life has been testimony to a complete misunderstanding of that cultural phenomenon.

Let us now return to some of the questions that were raised in the introductory part of this paper. After a surprisingly rapid liberation from communist domination in Czechoslovakia, will the Catholic Church reassume the leading role that it had in the 18th and 19th centuries? Will an ecumenical spirit prevail among Christians? Will the sceptical rationalism that spread so widely throughout Czech society during the first half of the 20th century prove more durable? Or will the intellectual and moral elite in the Czech nation envisage a broader type of ecumenism than one confined to the Christian denominations only? At present my answers to these questions can only be a matter of tentative assessment. According to the census of March 1991, 39.7 per cent of the population in the Czech republic declared themselves as non-believers, and 16.2 per cent did not identify their religious affiliation. For the rest, 39.2 per cent declared themselves as Catholics, 2.4 per cent as Protestants, 1.7 per cent as Czechoslovak (in fact Czech) Hussites, 0.2 per cent as Greek Orthodox and 0.5 per cent as belonging to other confessions (these included the Jews and some smaller Christian bodies). In Slovakia, non-believers count for less than 10 per cent, Catholics for over 63 per cent and Protestants about 8 per cent; 17.5 per cent are of unidentified affiliation.

On the whole it seems certain that the 'age of faith' has gone for good. However, it has not been replaced by an age of straightforward disbelief. Churches appear to be popular in so far as they provide pastoral care and charity to those in need. They are also popular for the warmth of their services, in which the musical element provides a key impulse for devotion. On the other hand, the dogmatic aspects of religion tend to be shunned; at best they are looked on as unavoidable accessories that need not be taken too seriously. The prevailing social climate in the West is favourable to such a modus vivendi between religion and what is supposed to be common sense. The churches, however, in particular the Catholic Church, are not happy with this situation. Since the Second Vatican Council there have been two contending schools of thought in the Catholic Church. Those who want to progress along the lines established by that council are opposed to those who prefer to stick to the established patterns. The present Pope, John Paul II, is of the more conservative tendency. Since his ethnic constituencies, so to speak, have been liberated, the Pope's appeal to them has weakened. Now the issue is not the fight against communism but how to build a new life, and new practical questions, such as abortion and women's rights, are on the agenda. The extent of religious education is also becoming an issue: it has already 
begun in schools, and private denominational schools are being established. It is not yet clear to what extent religious teaching might clash with lay teaching that claims to be based on scientific knowledge. Will there be quiet compromise, as is the prevailing practice in Western Europe, or are we going to see controversy of the kind that has emerged in some American states? Or will it be possible to reach a mutual understanding on the basis of a more explicit demarcation between the respective fields of concern of religion and science?

No genuine scientist can claim the ultimate validity of his or her theories. The more one knows, the more one realises how little our scientific understanding of the universe really explains. Science cannot provide a substitute for religious belief. It is, however, in a position to challenge religious faith in such a way that this faith has to redefine itself in order to become acceptable to rational, critical minds. History shows us that it is the conflicts between individual religions rather than between religion and science that have resulted in hatred, oppression and war.

Both the Renaissance and the Enlightenment had a dampening effect on religiosity. By contrast, Marxism-Leninism, because of its claim to be in sole possession of the truth - scientific truth - and because of its belligerent opposition to religion, had the opposite effect: it strengthened religious faith. And what about modern science, the heir of the epoch of Enlightenment? Being more aware of its limits and uncertainties than ever before, modern science is also more considerate towards genuine religious beliefs and feelings. Science is now better equipped to promote mutual understanding not only between itself and religion, but also between divergent religious views.

Fundamental moral values are after all common to all men. There are in my view four points on which all men of good will, believers and non-believers, can be - and need to be - in agreement:

1 God, however conceived, is the source of creative and moral force in the universe.

2 Of all creatures on the planet Earth, only human beings are endowed with the ability to draw from this source.

3 It is the duty of human beings to draw from this source as much as possible.

4 Human beings carry full responsibility for the whole planet and also for the universe as far as they can reach it.

In my view, this is the sense of the ecumenical endeavour in which the Czech intellectual vanguard is currently engaged. It is an ecumenism that respects pluralism of belief and that, after the many bitter experiences of the past, stands a chance of promoting fruitful cooperation among the adherents of a wide variety of confessions, both traditional and newly emerging on the scene.

\section{Notes and References}

This article was first presented as a paper at the conference 'Religion and the Resurgence of Capitalism' at Lancaster University in July 1991.

1 D. Odlozilik, The Hussite King: Bohemia in European Affairs 1440-1471 (New Brunswick, NJ, 1965), pp. 4-5.

2 Statistick' zpravodaj, 1946. Changes in religious affiliation in the Czech lands can be summarised as follows: 


\begin{tabular}{lcccc}
\hline & 1910 & 1921 & 1930 & 1947 \\
\hline Catholic & 95.0 & 82.0 & 78.6 & 75.8 \\
Protestant & 3.6 & 4.0 & 4.7 & 4.8 \\
Czechoslovak & - & 5.2 & 7.3 & 10.7 \\
Other Christians & - & 0.3 & 0.5 & 0.6 \\
Jews & 1.4 & 1.3 & 1.1 & 0.1 \\
Without denomination & - & 7.2 & 7.8 & 8.0 \\
\hline
\end{tabular}

This table shows the percentage of the total population in each confession and is derived from the 1910, 1921 and 1930 censuses, and a 1947 estimate from The Statesman's Yearbook (London, 1963). Data for years before 1947 also include the German population. Until 1991 Czechoslovak statistics did not report religious affiliation.

3 Translated from the quarterly Czech review Studie, Rome, no. 115 (1988), p. 48.

4 Studie, no. $120(1988)$, p. 48.

s Studie, no. 118-18 (1988), p. 364.

6 Studie, no. 118-19(1988), p. 382. 